\title{
Two Cases of Excluded Middle?
}

The November issue and this issue of the Christian Journal for Global Health each contain an article debating the two sides of whether and how Christian organizations should support family planning in global health settings. Wubbenhorst and Wubbenhorst contend that use of modern, artificial contraception inevitably portends a transition to or a mentality of acceptance and promotion of abortion. ${ }^{1}$ They also question whether terms such as "unplanned pregnancy" and "unmet need" contain unexamined presuppositions. In this issue, Professor Henry Mosley offers a vigorous response by providing evidence that modern contraceptive methods, in fact, prevent and reduce abortions. ${ }^{2}$ However, both sides of the argument contain areas that seem to us to be ripe for further comment.

Is it really the case, for example, that use of modern contraceptives inevitably leads to sympathy for abortion? There is no doubt that many secular organizations endorse abortion along with modern family planning methods, but this does not imply a necessary and logical progression. Would a family intending to space its children also intend to do away with an untimely pregnancy? We find it difficult to accept this connection as inevitable. At the same time, there is good reason to believe that societywide changes in sexual mores have accompanied the introduction of modern contraceptives as pointed out recently by Mary Eberstadt. ${ }^{3}$ Using historical, social, and legal reasoning, she concludes that, on a society wide basis, abortion and out-of-wedlock births have increased in parallel with increased use of modern contraceptives. She also argues that modern contraception makes pregnancy the sole responsibility of a woman, freeing men from an incentive to marry and an obligation to care for mother and child.

July 2018. Christian Journal for Global Health, 5(1):2-3.
Professor Mosley offers empirical evidence that introduction of modern family planning methods into societies where these had not been available resulted in reduced rates of abortion. Could these be special cases and is it appropriate to compare these examples with society-wide developments in the West since the 1960s?

Is there not a subtle psychological shift implied in the term "unplanned pregnancy?" Is it now expected that pregnancy be "planned" when formerly it was the natural outcome of a sexual relationship? It is since the introduction of modern contraception that use of the term "unexpected pregnancy" has developed currency. But how can pregnancy following sex be "unexpected?" Throughout all of nature, sexual relations serve the purpose of reproduction. In human beings, have we tried to change this? Is this natural? Does not the term "unplanned pregnancy" reverse the normal logic of sex?

Whilst the Wubbenhorsts tend to throw out modern contraception with the abortion bathwater, Mosley reasons that it can play an important role in the health of families and in certain low income settings and that it may not necessarily promote abortion. But does Professor Mosley go too far in implying that the demographic transition leaves us only a choice between high birth rates along with high maternal, infant, and childhood mortality or employment of modern contraceptive methods with attendant decreased birth rates and improved survival of mother, infant, and child? Is it true that without modern contraception, a reversion to developing world demographics is inevitable? In fact, birth rates declined substantially in Western countries prior to the introduction of modern contraception. ${ }^{4,5}$ It appears that appropriately motivated families can reduce their family size 
without a requirement for contraceptives. Professor Mosley's reaffirmation of "Population Bomb" logic is challenged by contemporary commentary on this subject. ${ }^{6}$ There are good reasons why such predictions ought to be regarded as dubious. ${ }^{7}$ Many variables are not scalar, functional relations between them are not known, they can be influenced by politics and fashion, and events are susceptible to being reflexive. ${ }^{7}$ But the main feature of such situations, as McGurn points out, is that such logic neglects the greatest resource available to us which is humanity. Humanity, especially when empowered by true religion, is capable of navigating successfully the ethics of family size without destroying innocent human life as well as the current challenge of demographic transition with its attendant consequences of elderly loneliness and abandonment.

\section{References}

1. Wubbenhorst MC, Wubbenhorst, JK. Should Evangelical Christian organizations support international family planning? Christ J Global Heal.
2017;4(3):21-39. Available from: https://doi.org/10.15566/cjgh.v4i3.184

2. Mosley WH. Why Evangelical Christians do support international family planning. Christ J Global Heal. 2018;5(1) https://doi.org/10.15566/cjgh.v5i1.205

3. Eberstadt M. The prophetic power of Humanae Vitae. First Things. 2018; Apr. Available from: https://www.firstthings.com/article/2018/04/theprophetic-power-of-humanae-vitae

4. Livingston G, Cohn D. Birth rates, 1920-2010

[Internet]. In Birth rate falls to a record low; decline Is greatest among immigrants. Pew Research Center Social and Demographic Trends. 2012 Nov 29. p. 3. Available from: http://www.pewsocialtrends.org/2012/11/29/u-sbirth-rate-falls-to-a-record-low-decline-is-greatestamong-immigrants/

5. Roser M. Children born per woman [Internet]. In Fertility rate. OurWorldInData.org. 2018. Available from: https://ourworldindata.org/fertility-rate

6. McGurn W. The population bomb was a dud. Wall Street Journal. 2018 Apr 30. Available from: https://www.wsj.com/articles/the-population-bombwas-a-dud-1525125341

7. Medawar P. Expectation and prediction. In Pluto's Republic. Oxford: Oxford University Press.1982. p. 302.

www.cjgh.org

July 2018. Christian Journal for Global Health, 5(1):2-3. 